\title{
Preference of Pygmy Rabbits (Brachylagus idahoensis) for Various Populations of Big Sagebrush (Artemisia tridentata)
}

\author{
SUSAN M. WHITE, JERRAN T. FLINDERS, AND BRUCE L. WELCH
}

\begin{abstract}
Pygmy rabbits were used in feeding trials to rute preference of 15 populations of 2 subspecies of big sagebrush (Artemisia tridentata ssp. vaseyana, Artemisia tridentata ssp. tridentata). Monoterpenoid content of sagebrush was determined for each population in the feeding trials and related to food preference. The rabbits showed no significant preference for one Artemisia subspecies over the other; instead, selection was made at the population level. There was no significant correlation between monoterpenoid content and dietary preference of pygmy rabbits.
\end{abstract}

It has been reported by a number of researchers that wintering mule deer prefer some populations and subspecies of big sagebrush (Artemisia tridentata) over others (Plummer et al. 1968, Hanks et al. 1971, Scholl et al. 1977, McArthur et al. 1979, Welch and McArthur 1979, Welch et al. 1981). Hanks et al. (1971) and Sheehy (1975) reported that wintering sheep expressed similar diffe rential preferences for populations and subspecies of big sagebrush. Determining wintering mule deer or sheep preferences for populations or subspecies of big sagebrush is an arduous and timeconsuming process. Paper chromatographic and ultraviolet light tests lack the sensitivity to differentiate preference among populations in a given subspecies (Hanks et al. 1971, and Stevens and McArthur 1974). Pygmy rabbits (Brachylagus idahoensis), described by Green and Flinders (1980) as having an "obligatelike" relationship with big sagebrush, may be useful as a laboratory test animal in evaluating the preferences of wintering sheep and mule deer for certain sagebrush populations.

Even though big sagebrush comprises 97 to $99 \%$ of the winter diet of pygmy rabbits, nothing is known about the preference of these animals for certain populations or subspecies of big sagebrush (Wilde 1978, Green and Flinders 1980, White et al. 1982). This study is the first part of a two-part project aimed at determining the usefulness of pygmy rabbits in evaluating animal preference for certain big sagebrush populations. The purpose of this study was to determine if pygmy rabbits prefer some populations of big sagebrush over others. A secondary purpose was to relate the monoterpenoid content of big sagebrush populations to possible preference differences (Barbar et al. 1969, Sheehy 1975, Scholl et al. 1977, Nagy and Regelin 1977).

\section{Methods and Materials}

A laboratory colony of 15 pygmy rabbits was established at Brigham Young University for use in this study. Rabbits were trapped at the U.S. Sheep Experiment Station near Dubois, Idaho. Upon arrival at the laboratory, rabbits were dusted for fleas and placed in individual pens. Every other day, rabbits received fresh sagebrush (Artemisia tridentata ssp. vaseyana and ssp. tridentata) from various locations around Provo, Utah. Guinea pig food pellets containing $17.0 \%$ crude protein, $4.0 \%$ crude fat, $12.0 \%$ crude fiber, and mineral supplement were continuously available

\footnotetext{
Authors are graduate research assistant, Range Science Department, Brigham Young University, Provo, Utah 84602; chairman, Botany and Range Science Department, Brigham Young University, Provo, Utah; research plant physiologist, USDA Forest Service, Intermountain Forest and Range Experiment Station, Shrub Sciences Laboratory, Provo, Utah 84601.

Manuscript received September 25, 1980.
}

to the rabbits. Ten rabbits were selected to determine preference for various subspecies and populations of big sagebrush.

FifterI populations of big sagebrush, which included eight populations of $A . t$. ssp. tridentata and 7 populations of $A . t$. ssp. vaseyana, were selected to test for pygmy rabbit dietary preference. Subspecies were identified by morphological and chemical criteria (Stevens and McArthur 1974, McArthur et al. 1979). Selection of the populations was based on sagebrush location and on the travel time needed to collect 2 distinct populations of each of the 2 subspecies.

The preference trial was initiated as a randomized block design consisting of 10 blocks per trial. A block consisted of a single rabbit in a $61 \times 77 \times 46 \mathrm{~cm}$ cage. Each of the rabbits had access to 4 different populations of big sagebrush at one time. Each trial consisted of 2 populations of $A$.t. ssp.tridentata and 2 populations of A.t. ssp. vaseyana. A test was composed of 3 trials. Vegetative samples of big sagebrush for a set of 3 trials or 1 test were collected by establishing 3 permanent $30-m$ transects. The nearest-neighbor method was used to select samples (Cole 1963). Samples were taken to the laboratory and frozen at $0^{\circ} \mathrm{C}$. The first of 3 successive trials began the following day. There were 2 major sampling periods: one in December and one in February. Because of deep snow and heavy deer use, some of the populations used in the December sampling period were not available for the February period. This would make comparisons between the two periods unreliable.

The locations of big sagebrush populations used in various tests are given in Table 1. A trial was conducted as follows: a 50 to $70-\mathrm{g}$ sample of the 4 different populations to be tested in 1 day was attached in each of the 4 corners of the rabbit pens and left for a 20 hour period. Weights were recorded before and after the sagebrush samples were placed in pens and differences in these weights, when corrected for weight loss, were recorded as the amount eaten by the rabbit. Five control samples per population were placed outside pens and weighed at the same time as test samples. This was done in order to provide a weight correction factor. In each trial, individual populations were randomized in the pens. The 3 replications within

Table 1. Locations of 15 Utah populations of big sagebrush (Artemisia tridentata) used to determine dietary preference of caged pygmy rabbits.

\begin{tabular}{lll}
\hline \hline Species & Population & City and county \\
\hline $\begin{array}{c}\text { Artemisia tridentata } \\
\text { vaseyana }\end{array}$ & Fairview Canyon & Fairview, Sanpete \\
& Hobble Creek I & Springville, Utah \\
& Park City & Park City, Summit \\
& Wallsburg & Wallsburg, Utah \\
& Silver City & Silver City, Juab \\
& Nephi Canyon & Nephi, Juab \\
& Hobble Creek II & Springville, Utah \\
& Colton & Soldier Summit, Utah \\
Artemisia tridentata & Utah Lake & Lehi, Utah \\
tridentata & Diamond Fork & Indianola, Sanpete \\
& West Nephi & Nephi, Juab \\
& Nephi Loop & Nephi, Juab \\
& Point of Mountain & Alpine, Utah \\
& St. John & St. John, Tooele \\
& Indianola & Indianola, Sanpete \\
\hline
\end{tabular}


1 test were totaled and the average amount eaten was tabulated. It should be noted that the rabbits had continuous access to guinea pig pellets and water.

Comparison of means between preference values for population and subspecies during individual feeding trials was analyzed using group comparisons based on equal and unequal variances (Huntsberger 1967). RUMMAGE, a computer program using expected mean squares in analysis of variance, was used to determine differences among test populations (Scott et al. 1976).

Material used in determining the monoterpenoid content for each population was collected from control samples at the end of each replication and stored in the laboratory freezer at $-35^{\circ} \mathrm{C}$. All tissues were ground in liquid nitrogen to prevent loss of monoterpenoids. Monoterpenoids were extracted by Soxhlet extraction with absolute ether, and gas chromatographic techniques were used to separate fractions (Welch and McArthur 1981). Fractions were expressed on a percent dry matter basis.

Linear and stepwise multiple regression analysis was the basis for relating monoterpenoid content to grams of tissue consumed. Seven dependent variables were used in the multiple linear regression. These variables were the concentrations of $\alpha$-thujone, camphor, $\alpha$-pinene, 1,8 cineol, $\beta$-thujone, terpineol, and total monoterpenoids.

\section{Results}

Results of feeding trials for the December and February tests are given in Table 2. In the December tests, an average of $12.2 \mathrm{~g} \mathrm{of} \mathrm{big}$ sagebrush was eaten per rabbit each 20 -hour testing period. During the same period, the rabbits ate an average of $15.8 \mathrm{~g}$ of guinea pig food pellets. Test 1 in December showed rabbits preferred big sagebrush from Diamond Fork $(5.3 \mathrm{~g})$ over sagebrush from
Indianola (2.3 g), Fairview Canyon ( $2.0 \mathrm{~g})$, and Hobble Creek I $(1.0 \mathrm{~g})$. In the December test 2, the rabbits preferred Park City (5.5 g) big sagebrush over big sagebrush from Wallsburg $(2.0 \mathrm{~g})$, Point of the Mountain $(3.1 \mathrm{~g})$, and from Utah Lake $(1.3 \mathrm{~g})$. December test 3 showed that rabbits preferred big sagebrush from Silver City (6.9 g) to sagebrush from West Nephi $(3.8 \mathrm{~g})$, St. John $(2.2 \mathrm{~g})$, and Nephi Canyon $(1.1 \mathrm{~g})$. In the December tests, the total mean consumption per rabbit of A.t. ssp. tridentata was $6.0 \mathrm{~g}$ and $6.2 \mathrm{~g}$ per population of A.t. ssp. vaseyana.

In February tests, an average of $19.5 \mathrm{~g}$ of big sagebrush per rabbit was eaten over each 20 -hour period. During the same period, rabbits ate $14.1 \mathrm{~g}$ of guinea pig pellets. Test 1 in February showed rabbits preferred big sagebrush from Hobble Creek II (7.8 g) and Diamond Fork ( $7.7 \mathrm{~g})$ over sagebrush from Indianola $(2.1 \mathrm{~g})$ and Colton $(1.9 \mathrm{~g})$. The second test in February indicated rabbits preferred Park City $(7.7 \mathrm{~g})$ and Wallsburg $(7.0 \mathrm{~g})$ samples over sagebrush from Utah Lake (2.3 g) and Point of the Mountain (1.8 g). The third test in February revealed rabbits had no significant preference for sagebrush from Nephi Loop (5.7 g), Silver City (5.4 g), St. John (4.7 g), or West Nephi (4.6 g). For the February tests, total mean consumption per rabbit of individual populations of A.t. ssp. tridentata and A.t. ssp. vaseyana was $9.6 \mathrm{~g}$ and $9.9 \mathrm{~g}$, respectively. (Note that we had to include three populations of ssp. tridentata in test 3 instead of two.)

Unfortunately, December tests 1 and 3 cannot be compared with February tests 1 and 3 as some of the sagebrush populations available in December were not available in February. Unavailability was due to snow depth and to heavy usage by wintering herds of mule deer. Test 2 of the 2 sampling periods can be compared. In both periods the Park City big sagebrush was the most preferred. Big sagebrush from Utah Lake and Point of the

Table 2. The preference of pygmy rabbits (Brachylagus idahoensis) for subspecies and populations of big sagebrush (Artemisia tridentata). Data expressed as grams consumed-two testing periods, December and February 1978-79.

\begin{tabular}{|c|c|c|c|c|c|}
\hline Testing period & Test & Populations & $\overline{\mathbf{x}}$ & Subspecies & $\overline{\mathbf{x}}$ \\
\hline \multirow[t]{3}{*}{ December } & 1 & $\begin{array}{l}\text { Diamond Fork }(t)^{!} \\
\text {Indianola }(t) \\
\text { Fairview Canyon (v) } \\
\text { Hobble Creek I (v) }\end{array}$ & $\begin{array}{l}5.3^{\mathrm{a} 2} \\
2.3^{\mathrm{b}} \\
2.0^{\mathrm{b}} \\
1.0^{\mathrm{b}}\end{array}$ & $\begin{array}{l}\text { tridentata } \\
\text { vaseyana }\end{array}$ & $\begin{array}{l}7.6^{a} \\
3.0^{b}\end{array}$ \\
\hline & 2 & $\begin{array}{l}\text { Park City (v) } \\
\text { Point of the Mountain (t) } \\
\text { Wallsburg (v) } \\
\text { Utah Lake (t) }\end{array}$ & $\begin{array}{l}5.5^{\mathrm{a}} \\
3.1^{\mathrm{b}} \\
2.0^{\mathrm{b}} \\
1.3^{\mathrm{b}}\end{array}$ & $\begin{array}{l}\text { vaseyana } \\
\text { tridentata }\end{array}$ & $\begin{array}{l}7.5^{\mathrm{a}} \\
4.4^{\mathrm{b}}\end{array}$ \\
\hline & 3 & $\begin{array}{l}\text { Silver City (v) } \\
\text { West Nephi }(t) \\
\text { St. John (t) } \\
\text { Nephi Canyon }\end{array}$ & $\begin{array}{l}6.9^{\mathrm{a}} \\
3.8^{\mathrm{b}} \\
2.2^{\mathrm{b}} \\
1.1^{\mathrm{b}}\end{array}$ & $\begin{array}{l}\text { vaseyana } \\
\text { tridentata }\end{array}$ & $\begin{array}{l}8.0^{\circ} \\
6.0^{\circ}\end{array}$ \\
\hline Period mean & & All populations & 3.0 & $\begin{array}{l}\text { vaseyana } \\
\text { tridentata }\end{array}$ & $\begin{array}{l}6.2^{n} \\
6.0^{n}\end{array}$ \\
\hline \multirow[t]{3}{*}{ February } & 1 & $\begin{array}{l}\text { Hobble Creek II }(v) \\
\text { Diamond Fork }(t) \\
\text { Indianola }(t) \\
\text { Colton }(v)\end{array}$ & $\begin{array}{l}7.8^{\mathrm{a}} \\
7.7^{\mathrm{a}} \\
2.1^{\mathrm{b}} \\
1.9^{\mathrm{b}}\end{array}$ & $\begin{array}{l}\text { tridentata } \\
\text { vaseyana }\end{array}$ & $\begin{array}{l}9.8^{\circ} \\
9.7^{\circ}\end{array}$ \\
\hline & 2 & $\begin{array}{l}\text { Park City (v) } \\
\text { Wallsburg (v) } \\
\text { Utah Lake (t) } \\
\text { Point of the Mountain (t) }\end{array}$ & $\begin{array}{l}7.7^{\circ} \\
7.0^{\mathrm{a}} \\
2.3^{\mathrm{b}} \\
1.8^{\mathrm{b}}\end{array}$ & $\begin{array}{l}\text { vaseyana } \\
\text { tridentata }\end{array}$ & $\begin{array}{r}14.7^{\circ} \\
4.1^{\mathrm{b}}\end{array}$ \\
\hline & $3^{3}$ & $\begin{array}{l}\text { Nephi Loop (t) } \\
\text { Silver City (v) } \\
\text { St. John (t) } \\
\text { West Nephi (t) }\end{array}$ & $\begin{array}{l}5.7^{\mathrm{a}} \\
5.4^{\mathrm{a}} \\
4.7^{\mathrm{a}} \\
4.6^{\mathrm{a}}\end{array}$ & $\begin{array}{l}\text { tridentata } \\
\text { vaseyana }\end{array}$ & $\begin{array}{l}5.3 \\
5.4^{3}\end{array}$ \\
\hline Period mean & & All populations & 4.9 & $\begin{array}{l}\text { vaseyana } \\
\text { tridentata }\end{array}$ & $\begin{array}{l}9.9^{3} \\
9.6\end{array}$ \\
\hline Mean of both periods & & All populations & 4.0 & $\begin{array}{l}\text { vaseyana } \\
\text { tridentata }\end{array}$ & $\begin{array}{l}8.0^{3} \\
7.8\end{array}$ \\
\hline
\end{tabular}

$\mathrm{i}_{\mathrm{t}}=$ Artemisia ridentata; $\mathrm{v}=$ Artemisia tridentata vaseyana.

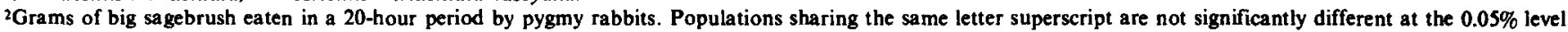
${ }^{3} A$ population of A.t. tridentata had to be substituted for a population of A.t. vaseyana. 
Table 3. The relationship between monoterpenoids and the preference of pygmy rabbits for populations of big sagebrush. Data expressed as correlation coefficient $(r)$ and coefficient of determination $\left(r^{2}\right)$.

\begin{tabular}{|c|c|c|c|c|c|c|c|c|}
\hline & \multicolumn{8}{|c|}{ Monoterpenoids } \\
\hline & $\alpha$-Pinene & Camphor & 1,8 Cineol & $\alpha$-Thujone & $\beta$-Thujone & d-Camphor & Terpineol & Total \\
\hline$r$ & -0.16 & 0.14 & -0.14 & -0.34 & -0.15 & 0.04 & -0.28 & -0.26 \\
\hline$r^{2}$ & .03 & .02 & .02 & .12 & .02 & .00 & .08 & .07 \\
\hline
\end{tabular}

Mountain were eaten sparsely in both periods. Consumption of the Wallsburg big sagebrush in December was also sparse, but high in the February period. We have no explanation for this difference.

The average monoterpenoid content of big sagebrush for all tests was $1.91 \%$ (data expressed on a dry matter basis-pool data from December and February). The largest fraction-pool data-was $\alpha$-thujone $(0.39 \%)$; camphor was the second largest $(0.29 \%)$. Total monoterpenoid content for December averaged $2.17 \%$. A.t. ssp. vaseyana $(2.48 \%)$ contained a higher nonsignificant amount $(p=0.05)$ of total monoterpenoid than did A.t. ssp. tridentata $(1.87 \%)$. Camphor $(0.28 \%)$ was the largest individual monoterpenoid fraction for the December period. A.t. ssp. vaseyana $(0.33 \%)$ contained a greater nonsignificant $(p=0.05)$ amount of camphor than did A.t. ssp. tridentata $(0.24 \%)$.

Total monoterpenoid content for February (1.66\%) was not significantly different than that for December. A.t. ssp. vaseyana ( $1.90 \%$ ) again contained more nonsignificant total monoterpenoids than did A.t. ssp.tridentata (1.44\%). In February, $\alpha$-thujone was the single largest monoterpenoid fraction $(0.57 \%)$. Camphor was the second largest fraction for February testing ( $0.31 \%$ dry matter).

Total monoterpenoid content showed no significant correlation to preference $(r=-0.26)$, when grams of sagebrush consumed was used as the dependent variable (Table 3). However, the monoterpenoid fraction @-thujone $(r=-0.34)$ had a statistically significant negative influence on preference. Other monoterpenoid fractions, camphor $(r=-0.14), \alpha$-pinene $(r=-0.16), 1,8$ cineol $(r=$ $-0.14), \beta$-thujone $(r=-0.15)$, and terpineol $(r=-0.28)$ had no significant correlation with preference. Stepwise multiple linear regression could account for $59 \%$ of the variation in dietary preference for sagebrush; however, this value was not statistically significant $(p=0.05)$.

\section{Discussion}

Overall, the pygmy rabbits showed no preference for either subspecies tridentata or vaseyana. On a per test (one test, December test 1), however, ssp. tridentata was significantly preferred over ssp. vaseyana; but ssp. vaseyana was significantly preferred over ssp.tridentata in 2 tests (December test 2, February test 2). Sheehy (1975) reported that mule deer preference for taxa of big sagebrush was expressed at the subspecies level and not at the population level. Hanks et al. (1973) reported similar results. Scholl et al. (1977), Welch and McArthur (1979), and Welch et al. (1981) have shown that some accessions of ssp. vaseyana grown on a common site were not significantly preferred by wild, wintering mule deer over some accessions of ssp.tridentata. While it is a good rule of thumb that ssp. vaseyana is preferred by wintering mule deer over ssp. tridentata, it appears that some populations of ssp. tridentata may be preferred as well as some populations of ssp. vaseyana (Scholl et al. 1977, McArthur and Plummer 1978, Welch et al. 1981).

Lack of a significant relationship between preference and the monoterpenoid content of the forage has been reported for other animals (Scholl et al. 1977, Radwan and Crouch 1978). Scholl et al. (1977), studying the involvement of monoterpenoids (sagebrush) in browse preference of wintering mule deer, found that the monoterpenoid content in sagebrush accounted for only $21 \%$ of the observed variation. Radwan and Crouch (1978), studying the preference of blacktail deer for families of Douglas-fir, found that the families varied significantly in yield and composition of monoterpenoids, but the differences were not related to deer preference. These reports contrast with the findings of Nagy and Regelin (1977) and Barbar et al. (1969). Nagy and Regelin (1977), using pelleted feed of varying monoterpenoid content, found that deer selected pelleted feeds that had the lowest monoterpenoid content. Barbar et al. (1969) reported that sage grouse selected sagebrush containing the lowest concentration of monoterpenoids.

This study has demonstrated that pygmy rabbits differentially prefer certain populations of big sagebrush over others. The use of pygmy rabbits as an indicator species for dietary palatability of big sagebrush will be tested in future work with sagebrush populations preferred by mule deer, pronghorn antelope, and sage grouse.

\section{Literature Cited}

Barbar, T.A., J.G. Nagy, and T.A. May. 1969. Nutrition and dietary preference of penned sage grouse. Proc. 6th Biennial Western States Sage Grouse Workshop, p. 180-186.

Cole, C.F. 1963. Range survey guide. Grand Teton National Hist. Ass. USDI, Grand Teton National Park, $18 \mathrm{p}$.

Cook, C.W., L.A. Stoddart, and L.E. Harris. 1954. The nutritive value of winter range plants in the Great Basin. Utah Agr. Exp. Sta. Bull. 372,56 p.

Green, J.S., and J.T. Flinders. 1980. Habitat and dietary relationship of the pygmy rabbit. J. Range Manage. 33:136-142.

Hanks, D.L., J.R. Brunner, D.R. Christensen, and A.P. Plummer. 1971. Paper chromatography for determining palatability differences in various strains of big sagebrush. USDA FS Res. Pap. INT-101, 9 p. Intermountain Forest and Range Exp. Sta., Ogden, Utah.

Huntsberger, D.V. 1967. Elements of statistical inference. Allyn and Bacon, Inc., Boston, Mass.

McArthur, E.D., and A.P. Plummer. 1978. Biogeography and management of native western shrubs: A case study Section Tridentatae of Artemisia. Great Basin Nat. Mem. 2:229-243.

McArthur, E.D., A.C. Blauer, A.P. Plummer, and R. Stevens. 1979. Characteristics and hybridization of important Intermountain shrubs. III. Sunflower family. USDA FS Res. Pap. INT-220, 82 p. Intermountain Forest and Range Exp. Sta., Ogden, Utah.

Nagy, J.G., and W.L. Regelin. 1977. Influence of plant volatile oils on food selection by animals. X1IIth Congr. Game Biol. 13:225-230.

Plummer, A.P., D.R. Christensen, and S.B. Monsen. 1968. Restoring big game range in Utah. Utah Div. Wildl. Resources Pub. 68-3, 183 p.

Rad wan, M.A., and G.L. Crouch. 1978. Selected chemical constituents and deer browsing preference of Douglas-fir. J. Chem. Ecol. 4:675-683.

Scholl, J.P., R.G. Kelsey, and F. Shafiza deh. 1977. Involvement of volatile compounds of Artemisia in browse preference by mule deer. Biochem. Systm. Ecol. 5:291-295.

Scott, D.T., C.R. Bryce, and M.W. Carter. 1976. Rummage-A general linear model data analysis system. Brigham Young University Stat. Dept., Provo, Utah.

Sheehy, D.P. 1975. Relative palatability of seven Artemisia taxa to mule deer and sheep. M.S. Thesis. Oregon State Univ., Corvallis.

Stevens, R., and E.D. McArthur. 1974. A simple field technique for identification of some sagebrush taxa. J. Range Manage. 27:325-326.

Welch, B.L., and E.D. McArthur. 1979. Feasibility of improving big sagebrush (Artemisia tridentata) for use on mule deer winter ranges. In: J.R. Goodin and D.K. Northington (eds.), Proc. Internat. Arid Lands Conf. Plant Resour. Texas Tech. Univ., Lubbock. p. 452-473.

Welch, B.L., and E.D. McArthur. 1981. Variation of monoterpenoid content among subspecies and accessions of Artemisia tridentata grown in a uniform garden. J. Range Manage. 34:380-384.

Welch, B.L., E.D. McArthur, and J.N. Davis. 1981. Differential preference of wintering mule deer for accessions of big sagebrush and black sagebrush. J. Range Manage. 34:409-411.

White, S.M., B.L. Welch, and J.T. Flinders. 1982. Monoterpenoid content of pygmy rabbit stomach ingesta. J. Range Manage. 34:107-109.

Wilde, D.B. 1978. A population analysis of the pygmy rabbit (Sylvilagus idahoensis) on the INEL site. Ph.D. Diss. Idaho State Univ., Pocatello 172.p. 